\title{
Quality changes of Longissimus dorsi and Semimembranosus muscles and perirenal adipose tissue during frozen storage of lambs fed dihydroquercetin or dry distilled rose petals supplemented diet
}

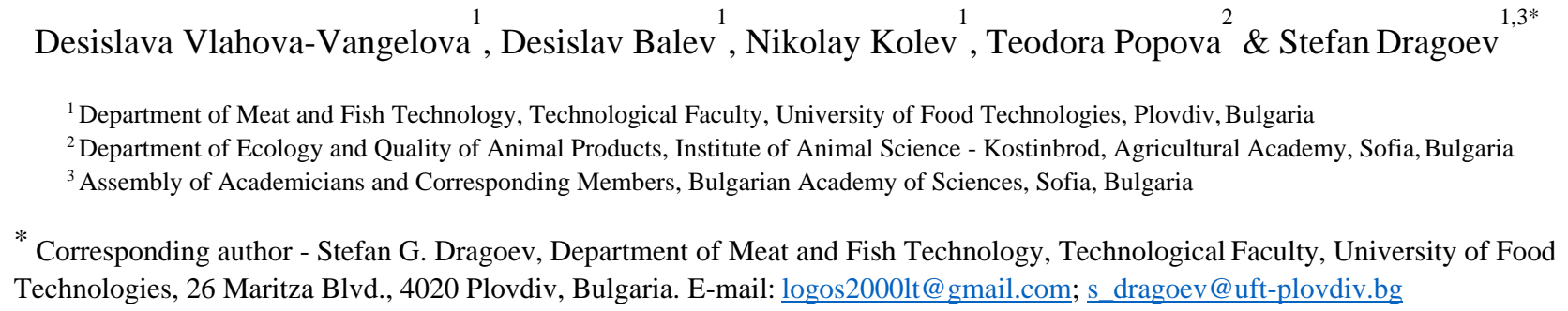

\section{Abstract}

The aim of study was to determine the changes of frozen stored of Longissimus dorsi and Semimembranosus muscles and perirenal adipose tissue from lambs (the Bulgarian Dairy Synthetic population sheep), fed a diet supplemented by $7.5 \mathrm{mg}$ dihydroquercetin (DQ) or $545 \mathrm{mg}$ dry distilled rose petals (DDRP)/kg life weight/d. Three groups of $10 \mathrm{male}$ lambs aged 65 days were fed 50 days ad libitum: a control (ground alfalfa + granular compound feed) and two experimental groups (the same diet + the addition of phytonutrients). Samples were collected $1 \mathrm{~d}$ post mortem. A half of them were analyzed immediately. Another half was vacuum-packed, quickly frozen at $-40^{\circ} \mathrm{C}$ and stored for $365 \mathrm{~d}$ at $-18^{\circ} \mathrm{C}$. Supplementing of the lamb's diet with polyphenol-rich phytonutrients reduces with $6.9-12.9 \%$ the aerobic plate count, $9.3-25.3 \%$ the $\alpha$-aminoacidic nitrogen, 31.8 - 45.9\% the protein carbonyls and $38.9-63.4 \%$ TBARS $(\mathrm{p} \leq 0.05)$ more pronounced in the $\mathrm{m}$. Longissimus dorsi from lambs fed with $545 \mathrm{mg} \mathrm{DDRP} / \mathrm{kg} / \mathrm{d}$. Further studies are needed to provide a more pronounced inhibitory effect on oxidation processes in frozen lamb.

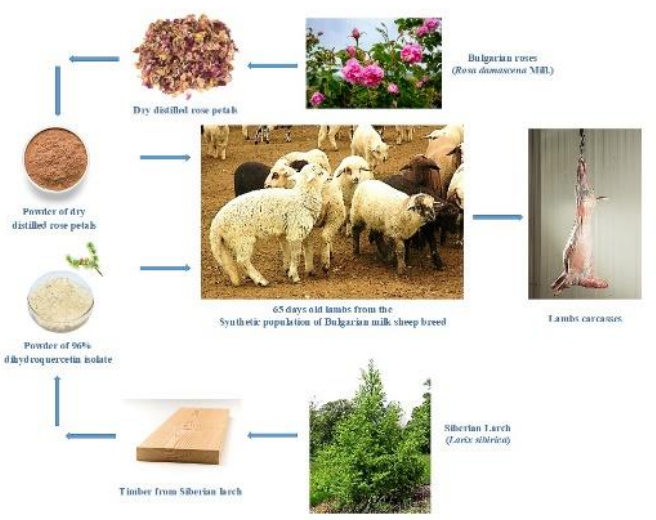


Lamb meat freezing and storing for a long period of time at $-18^{\circ} \mathrm{C}$ is a practice that has arisen from the new structure of markets in a globalizing world [1]. Hypermarket chains require that suppliers of frozen lamb should guarantee an even longer shelf life without adversely affecting its quality and safety [2]. During longer storage of frozen lamb lipids are oxidized [3]. For these reasons a variety of approaches have been proposed to mitigate the effects of freezing on the quality of lamb such. A new opportunity to stabilize the quality of long-stored frozen lamb is the addition of natural biologically active phytonutrients to the feed [4]. According to Surai [5] polyphenols (mainly flavonoids) may be even more effective than vitamins $\mathrm{E}$ and $\mathrm{C}$. Among the compounds having antimicrobial and antioxidant properties discuss the bioflavonoid dihydroquercetin (DQ). Its effectiveness in cattle's, pig's, broiler's, chicken's or bee's [6] feeding has been reported. Another natural source of polyphenols is dry distilled rose petals (DDRP), a by-product of the rose oil industry. They contain more than 30 polyphenolic compounds including [7] and are characterized with antioxidant and antibacterial properties [8]. Therefore, the aim of this study was to identify the quality changes during frozen storage of m. Longissimus dorsi, m. Semimembranosus and perirenal adipose tissue from lambs fed a diet supplemented by dihydroquercetin or dry distilled rose petals.

\section{Materials and Methods}

\section{Animals and experimental design}

The experiments were performed with 30 clinically healthy male lambs aged 65 days, equal in live weight. The lambs were divided into three groups with 10 lambs fed ad libitum for 50 days. The control group (C) was fed with ground alfalfa + pelleted compound feed. The experimental groups (DQ) and (DDRP) were fed with the same diet supplemented with $7.5 \mathrm{mg} \mathrm{DQ} / \mathrm{kg} / \mathrm{d}$ or $545 \mathrm{mg} \mathrm{DDRP} / \mathrm{kg} / \mathrm{d}$ respectively. Similar doses have been used in pig diet supplementation, which have a complex stomach and physiological peculiarities in digesting food [9]. The composition of the feed, information on the weights of the lambs before and after the trial together with growth rates and intakes and the slaughter procedure are described in details in previous our work [10]. The experiments were carried out in accordance with the recommendations of the European Convention for the Protection of Vertebrate Animals Used for Experimental and Other Scientific Purposes, Regulation (EC) No. 1099/2009 of the Council, Recommendation 2007/526/EC of the Commission and the Law on Veterinary Medicine in Bulgaria. The experiment was coordinated and approved by the Bulgarian Commission on Scientific Ethics, in compliance with Council Directive 2010/63/EU. Lambs' carcasses were chilled for $24 \mathrm{~h}$ at $0-4^{\circ} \mathrm{C}$ (day 1 of the experiment). The chilled carcasses were divided into two halves. From the left halves of each of the groups were removed m. Longissimus thoracis et lumborum (between 9 and 15 thoracic vertebrae, hereinafter referred to as m. Longissimus dorsi), m. Semimembranosus and perirenal adipose tissue (fat). The chilled muscles of the left halves of the carcasses are divided into two equal parts. The first - to determine the microbiological status and color characteristics, the second - minced in a mincer with a mesh diameter of $3 \mathrm{~mm}$, collected together to prepare mean sample. Homogenization was done using homogenizer (Mechanika Precyzyjna, Model type ST-2). Final homogenate was sent for further analysis (1 d post mortem). were thawed without unpacking. After thawing, the above procedure is repeated. 


\section{$72 \quad$ Phytonutrients}

73 The powdered DQ was supplied by Flavitlife Bio JSCo (Sofia, Bulgaria). It contained 96\% dihydroquercetin, 3\%

74 dihydrokaempferol and $1 \%$ naringenin.

75 The distilled rose petals were delivered by Bulattars Production Company Ltd (Pavel Bania, Bulgaria). After pressing,

76 the petals were dried for $24 \mathrm{~h}$ at $65^{\circ} \mathrm{C}$ and ground to a particle size $<0.4 \mathrm{~mm}$. Details of the basic polyphenol indices,

77 identification and quantification of polyphenol components and antioxidant activity of the DDRP can be found in

78 previous our work [7].

\section{Proteolysis and oxidative status of total proteins}

81 The $\alpha$-aminoacidic nitrogen was determined by the ninhydrin method modified by Garrido et al. [11].

82 The protein oxidation was measured spectrophotometrically at $370 \mathrm{~nm}$ as protein dinitrophenylhydrazones included in the bases upon absorption of $21.0 \mathrm{mM}^{-1} \mathrm{~cm}^{-1}$ [12]. Due to the relatively limited protein content of fats and their very low amount in lamb carcasses similar analyses for perirenal adipose tissue were not performed.

\section{Oxidative status of total lipids}

87 Extraction of total lipids was performed by the method of Bligh and Dyer [13]. The oxidative status of total muscle lipids and those of perirenal adipose tissue are characterized by: the degree of lipolysis expressed by acid value (AV) according to ISO 660:2009 [14]; the levels of lipid hydroperoxides (primary products of lipid peroxidation) expressed by peroxide value (POV) and malondialdehyde (MDA) (secondary products of lipid peroxidation) expressed TBARS [15].

92 The peroxide value was measured based on the oxidation of $\mathrm{Fe}^{2+}$ to $\mathrm{Fe}^{3+}$ in the presence of hydroperoxides and the 93 formation of a color complex between obtained $\mathrm{Fe}^{3+}$ and SCN [16] with some modification. The extracted lipids (0.1 g)

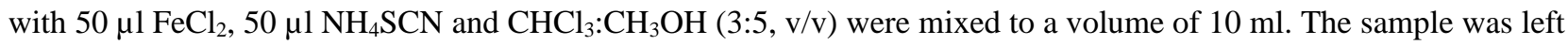
for $10 \mathrm{~min}$ and the absorption was measured at $507 \mathrm{~nm}$ against a control prepared from $0.1 \mathrm{~g}$ of total lipids, $50 \mu \mathrm{l}$ of $\mathrm{NH}_{4} \mathrm{SCN}, \mathrm{CHCl}_{3}: \mathrm{CH}_{3} \mathrm{OH}(3: 5, \mathrm{v} / \mathrm{v})$ to a volume of $10 \mathrm{ml}$. POV was calculated by equation (1):

$\mathrm{A}$ is the concentration reported on the standard line, $\mu \mathrm{eqFe} \mathrm{Fe}^{3+} / \mathrm{ml}$;

$a$ is the amount of total lipid sample taken for analysis, g;

10022 is the conversion factor of $\mu$ eqFe ${ }^{3+}$ to meqO$_{2}$.

TBARS were determined by measuring the absorption of samples at $532 \mathrm{~nm}$ on a Camspec M 550 double beam UVVis spectrophotometer (Spectronic CamSpec Ltd, Garforth, UK).

\section{Fatty acid profiles}

105 The fatty acid composition of the total lipids was determined by gas chromatography (GC) after transmethylation of the samples with $2 \% \mathrm{H}_{2} \mathrm{SO}_{4}$ in $\mathrm{CH}_{3} \mathrm{OH}$ at $50^{\circ} \mathrm{C}$ (ISO 12966-2:2011). Fatty acid methyl esters (FAME) were purified by 
6890 Plus (Agilent Technologies, Santa Clara, USA) equipped with 5793 mass-selective detector (Agilent Technologies, Santa Clara CA, USA) and with capillary column SP 2380 - $30 \mathrm{mx} 0.25 \mathrm{~mm}$ x $0.25 \mu \mathrm{m}$ (Supelco, Belefonte PA, USA). The column temperature was programmed from $70^{\circ} \mathrm{C}(1 \mathrm{~min})$ at $6{ }^{\circ} \mathrm{C} / \mathrm{min}$ to $190^{\circ} \mathrm{C}(0 \mathrm{~min})$ at $10^{\circ} \mathrm{C} / \mathrm{min}$ to $250^{\circ} \mathrm{C}(0 \mathrm{~min})$; the injector and detector temperatures are maintained at $250^{\circ} \mathrm{C}$. Hydrogen is a carrier gas at a flow rate of $0.8 \mathrm{ml} / \mathrm{min}$ and the separation was $1: 50$. The identification of fatty acids was performed by comparing the retention times with those of a standard mixture of fatty acids subjected to GC under identical experimental conditions (ISO 12966-1:2014).

\section{Color properties}

The meat color properties were measured in three places on both sides of the two-centimeter incision from each muscle $(\mathrm{n}=10)$ made perpendicular to the direction of the muscle fibers $\left(24 \mathrm{~h}\right.$ and after thawing the samples to $1{ }^{\circ} \mathrm{C}$ on $365 \mathrm{~d}$ post mortem) by a Konica Minolta model CR-410 chromometer using the CIE L*, a*, b* system. The calibration step was determined against white reference standard no.18833116 ( $\mathrm{Y}=94.3, \mathrm{x}=0.3134$ and $\mathrm{y}=0.3197)$. The color components were measured nine times. The brightness of the color $\mathrm{L}^{*}$ (ranging from 0 black to 100 white), the red component of the color $\mathrm{a}^{*}$ (varying from - green to + red) and the yellow component of the color $\mathrm{b}^{*}$ (varying from - $\mathrm{b}$ blue to $+\mathrm{b}$ yellow) were measured at the following settings: aperture $=8 \mathrm{~mm}$, standard observer $2^{\circ}$ and light source D65 [19].

The total color difference $(\Delta \mathrm{E})[20]$ was also calculated by equation 2 :

$\Delta \mathrm{E}=\sqrt{\left(\mathrm{L}_{2}^{*}-\mathrm{L}_{1}^{*}\right)^{2}+\left(\mathrm{a}^{*}{ }_{2}-\mathrm{a}^{*}{ }_{1}\right)^{2}+\left(\mathrm{b}^{*}{ }_{2}-\mathrm{b}^{*}{ }_{1}\right)^{2}}$

where

$\Delta \mathrm{E}$ is the total color difference and

$\Delta \mathrm{L}^{*}, \Delta \mathrm{a}^{*}$ and $\Delta \mathrm{b}^{*}$ are the differences in the values of the color brightness $\left(\mathrm{L}^{*}\right)$, the red component of the color ( $\left.\mathrm{a}^{*}\right)$ and the yellow component of the color $\left(b^{*}\right)$ between the compared samples e.g., between the control and the corresponding experimental sample.

\section{Biogenic amines}

From a ground laboratory sample $10 \mathrm{~g}$ were weighed and transferred to a $50 \mathrm{~cm}^{3}$ conical flask with $10 \mathrm{~cm}^{3}$ of $0.4 \mathrm{M}$ perchloric acid. The mixture was stirred on a shaker for $30 \mathrm{~min}$. The homogenized sample was centrifuged for $10 \mathrm{~min}$ at 1,000 $\times \mathrm{g}$ and the separated supernatant was filtered through filter paper (Watman 1). To $1 \mathrm{~cm}^{3}$ of the obtained extract were added $50 \mu \mathrm{l}$ of the internal standard solution (1,000 ppm 1,7-diaminoheptane solution), $200 \mu \mathrm{l}$ of $2 \mathrm{~N}$ sodium hydroxide solution, $300 \mu \mathrm{l}$ of saturated sodium bicarbonate solution and $2 \mathrm{ml}$ of dansyl chloride solution (10 $\mathrm{mg} / \mathrm{ml})$. The sample was incubated in the dark at room temperature for $15 \mathrm{~min}$. A hundred $\mu \mathrm{l}$ of $\mathrm{NH}_{4} \mathrm{OH}$ was added to remove residual dansyl chloride. After staying for $5 \mathrm{~min}$ at room temperature the volume of the reaction mixture was brought to $5 \mathrm{ml}$ with acetonitrile and centrifuged for $5 \mathrm{~min}$ at $2,500 \times \mathrm{g}$. This sample was filtered through a syringe filter with a PVDF membrane (pore size $0.45 \mu \mathrm{l}$ ). The filtered sample ( $20 \mu \mathrm{l})$ was injected into the HPLC injector of the Hitachi LaChrom Elite ${ }^{\circledR}$ HPLC system (Hitachi High Technologies America, Inc., Schaumburg, IL, USA), equipped with a diode array detector (DAD), ELITE LaCHrome software and a Purospher STAR column (C18) (4.6 x $150 \mathrm{~mm} 5 \mu \mathrm{m}$ particle size). A mixture of acetonitrile and water in a volume ratio of 70:30 was used as the mobile phase. The mobile phase was pre-filtered through a membrane filter with a pore size of $0.45 \mu \mathrm{m}$ and subjected to degassing in an ultrasonic 
bath. The flow rate is $0.8 \mathrm{ml} / \mathrm{min}$. There was a $10 \mathrm{~min}$ wait phase before the next analysis so that the equilibrium in the column could be restored. The absorption of the dansylated biogenic amine derivatives was recorded at $254 \mathrm{~nm}$ by the UV detector of the HPLC system and the final amounts were calculated using standard curves for five biogenic amines: putrescine, cadaverine, tyramine, histamine and 1,7-diaminoheptane. The results obtained are presented as $\mathrm{mg} / \mathrm{kg}$ dry matter.

\section{Microbiological analysis}

154 The microbiological status of the samples was established by bacteriological tests carried out in accordance with the microbiological criteria of Regulation (EC) № 1441 of 05.12.2007 according to ISO 4833:2001 [21]. Upon opening each vacuum pack ( $\mathrm{n}=10$ for each muscle), 15 grams of sample are taken under sterile conditions. This is followed by fine chopping and ten-fold dilution with saline in a Stomacher bag at 230 RPM for 2 minutes. For this purpose, a Stomacher 400 circulator was used.

\section{Statistical analysis}

A two-way ANOVA was used to determine whether the variability of the outcomes is due to chance or to the two factors in the analysis - type of diet (Control, DQ or DDRP) and time of frozen storage ( 1 or 365 days) (for each type of tissue, separately), and to determine whether there is a two-way relationship among variables on an outcome. The symbol * indicates significance ( $\mathrm{p} \leq 0.05)$ of both factors (type of diet and time of storage) and their interaction; and ** indicates significance $(\mathrm{p} \leq 0.05)$ only for the factor time of storage. Results were presented as means \pm standard error of the means $(\mathrm{SEM})$. The measurements were made in ten repetitions $(\mathrm{n}=10)$. The statistical package Microsoft Excel Office Professional Plus 2010 was used.

\section{Results and Discussion}

171 The levels of $\alpha$-aminoacidic nitrogen in the studied samples on $1 \mathrm{~d}$ post mortem fluctuated within narrow limits (between $1722.10-2.50 \mathrm{mg} \mathrm{Leu} / \mathrm{g})$ although they are significantly $(\mathrm{p} \leq 0.05)$ different (Table 1). After $365 \mathrm{~d}$ of storage of frozen $173 \mathrm{lamb}$ muscles at $-18^{\circ} \mathrm{C}$ the proteolytic processes deepen and the content of $\alpha$-aminoacidic nitrogen increases $3.6-4.2$ 174 times. This increase was more pronounced in control samples in both muscles. As a result, mitochondrial and lysosomal enzymes, heme iron and other prooxidants are released from the damaged microstructure of the muscle cells which lead an accelerated protein oxidation [22]. Elevated levels of $\alpha$-aminoacidic nitrogen may also be due to the decreased activity of $\mathrm{Ca}^{2+}$ ATPase and the increased activity of $\mathrm{Mg}^{2+}$-EGTA-ATPase - enzymes involved in the denaturation of myosin and troponin-tropomyosin complex in frozen muscles [23]. The addition of phytonutrients to the feed to some extent limits the accumulation of $\alpha$-aminoacidic nitrogen during the one-year storage of frozen lamb. This phenomenon is more pronounced in samples DDRP in $\mathrm{m}$. Longissimus dorsi. Probably in biological systems in vivo the polyphenolic compounds of DDRP inhibit muscle proteolytic enzyme systems by a still unclear mechanism [5]. Similar trends were found for protein carbonyls whose values compared to control samples were significantly lower in frozen samples DDRP in $\mathrm{m}$. Longissimus dorsi as well as in $\mathrm{m}$. Semimembranosus (Table 1). The oxidative degradation of frozen meat is provoked by the formation and growth of ice crystals. They cause mechanical damage to membranes and other cellular 
structures. This increases the concentration of prooxidants in the unfrozen phase of meat. Compared to samples DDRP, levels of protein carbonyls in samples DQ of $\mathrm{m}$. Semimembranosus are slightly smaller. These results confirm the hypothesis that the metabolic profile of muscles affects the oxidative stability of muscle proteins. They are evidence that the addition of $545 \mathrm{mg}$ DDRP/ $/ \mathrm{kg} / \mathrm{d}$ to lambs' diet can successfully inhibit proteolysis and protein oxidation in $\mathrm{m}$. Longissimus dorsi. According to Leygonie et al. [22] there is a strong interdependence between protein denaturation and protein oxidation (carbonyl formation). More significant protein oxidation enhances myosin heavy chain degradation (MHC) but has little effect on actin degradation [24]. The elevated levels of protein carbonyls in frozen lamb muscles stored for $365 \mathrm{~d}$ at $-18^{\circ} \mathrm{C}$ are probably due to the autooxidation of myoglobin. It is accompanied by the formation of carbonyl derivatives of myofibrillar proteins as a result of their interaction with by-products of lipid oxidation such as malondialdehyde (MDA). Our results are in unison with the hypothesis of Traore et al. [25] that during meat cold storage protein oxidation levels increase insignificantly.

\section{Changes in the total lipids of lamb's muscles and perirenal fatty tissue}

The AV of the lipids extracted from $\mathrm{m}$. Longissimus dorsi in samples DQ and DDRP on $1 \mathrm{~d}$ post mortem is less ( $\mathrm{p} \leq$ 0.05 ) with approx. $15 \%$ and AV from perirenal adipose tissue is less with about 15\% and resp. 7\%, compared to controls (Table 2). A similar trend was found after $365 \mathrm{~d}$ of frozen storage where the AV in samples DQ was more than 17\% and in samples DDRP it was with approx. 5\% lower than the one of controls. Both on $1 \mathrm{~d}$ post mortem and after $365 \mathrm{~d}$ of frozen storage this indicator has the lowest values in samples DQ of m. Semimembranosus. After $365 \mathrm{~d}$ of frozen storage the AV of perirenal adipose tissue was found to be the lowest in samples DQ. Relatively low levels of both primary (POV) and secondary (TBARS) products of lipid oxidation were found, both on $1 \mathrm{~d}$ post mortem and after $365 \mathrm{~d}$ frozen storage of the samples (Table 2). This was the idea of the experiment: to provide a set of antioxidants through feed supplements to help the lambs' organism to build an integrated antioxidant system. It was established that in all samples on $1 \mathrm{~d}$ post mortem the POV varies between $0.105-0.126 \mu$ eqO $\mathrm{O}_{2} / \mathrm{g}$ lipids. After 365 $\mathrm{d}$ of frozen storage some reduction in POV levels was found compared to those found on $1 \mathrm{~d}$ post mortem. They vary between 0.064-0.075 $\mu$ eqO $\mathrm{O}_{2} / \mathrm{g}$ lipids. An exception was observed only in control samples of $\mathrm{m}$. Semimembranosus which are significantly higher, both on $1 \mathrm{~d}$ post mortem $(0.126 \mu \mathrm{eqO} / \mathrm{g}$ lipids $)$ and after $365 \mathrm{~d}$ of frozen storage $(0.123 \mu \mathrm{eqO} / \mathrm{g}$ lipids) resp. (Table 2). Tissue hydroperoxides (derivatives of free radicals) are unstable structures with proven toxicity [26]. They undergo chemical transformations and turn into secondary products of lipid oxidation. Such reactions need 2- $4 \mathrm{~h}$ at $37^{\circ} \mathrm{C}$ to carry out [26]. This explains the relatively low POV established on $1 \mathrm{~d}$ post mortem. The formation of approx. $70 \%$ of the non-polar peroxides due to the change in fatty acid composition and heme iron content [26]. This can explain the lower POV values found in the samples after $365 \mathrm{~d}$ of frozen storage.

It was found that TBARS in two lamb muscles were statistically $(\mathrm{p} \leq 0.05)$ distinguishable but varied within an extremely small range: $0.21-0.70 \mathrm{mg} \mathrm{MDA} / \mathrm{kg}$ ( $1 \mathrm{~d}$ post mortem) and 0.10-0.41 mg MDA/kg (after $365 \mathrm{~d}$ of frozen storage) (Table 2). In samples of perirenal adipose tissue TBARS ranged between 0.10-0.79 mg MDA/kg (Table 2) and in two muscles frozen samples DDRP and DQ it was lower than the one in control samples. As mentioned above, MDA was one of the secondary derivatives of the lipid-oxidation reactions. It is able to react with the breakdown products of proteins and to form carbonyl derivatives. Therefore, the oxidation of proteins and lipids is interrelated [23]. The MDA can react with a wide range of compounds or form dimers or trimers. Consequently, the amount of MDA that can react 
with TBA decreases and this results in reduced TBARS. This explains the relatively lower levels reported by us for TBARS after 365 days of frozen storage. Due to the presence of sufficient unfrozen water in the samples at $-18^{\circ} \mathrm{C}$ biochemical reactions may occur, although with less speed [27]. The addition of DDRP to the lamb's diet can be used as appropriate tool for inhibiting the lipolysis in muscle tissue. Neither this supplement nor the addition of DQ significantly affect the initiation and development of lipid peroxidation in lamb muscles but they reduce by about $44 \%$ the levels of MDA in perirenal adipose tissues. At the intake $7.5 \mathrm{mg}$ $\mathrm{DQ} / \mathrm{kg} / \mathrm{d}$ and $545 \mathrm{mg}$ DDRP $/ \mathrm{kg} / \mathrm{d}$ the polyphenolic compounds are not sufficient to provide a more pronounced effective antioxidant protection. In conclusion, the factors of negative temperature and one-year frozen storage are mainly responsible for the reduction of oxidative processes in the fraction of total muscle lipids. Both POV and TBARS decrease significantly $(\mathrm{p} \leq 0.05)$ after $365 \mathrm{~d}$ of frozen storage. Further studies are needed to determine whether the administration of higher doses of DQ and DDRP in small ruminants will be able to provide a more pronounced inhibitory effect on lipid oxidation in muscles.

\section{Fatty acid profiles of lamb's muscles and perirenal fatty tissue}

Changes in the fatty acid compositions of total lipids extracted from m. Longissimus dorsi, m. Semimembranosus and perirenal adipose tissue after $365 \mathrm{~d}$ of frozen storage at $-18^{\circ} \mathrm{C}$ are too divergent (Table 3). Feeding dry diets enriched with phytonutrients increases the levels of unsaturated fatty acids as well as stearic acid (C18:0) in muscle lipids and fat depots [28] but we found similar tendence only in samples DQ. After $365 \mathrm{~d}$ frozen storage the lowest content of SFA was found in samples DDRP of m. Longissimus dorsi and in samples DQ of m. Semimembranosus and perirenal adipose tissue at the expense of an increase in the proportion of monounsaturated fatty acids (MUFA) (Table 3). Additional experiments are needed to elucidate the nature of the interactions between breed, age and feeding conditions that affect the fatty acid composition of lamb's lipids and fats [28]. The differences found may be due to the relatively small proportion of the phospholipid fraction against the fraction of neutral lipids and the different content of MUFA in both studied muscles and in perirenal adipose tissue.

\section{Color characteristics}

After $365 \mathrm{~d}$ of storage at $-18^{\circ} \mathrm{C}$ a significant $(\mathrm{p} \leq 0.05)$ increase in color brightness $\left(\mathrm{L}^{*}\right)$ red $\left(\mathrm{a}^{*}\right)$ and yellow $\left(\mathrm{b}^{*}\right)$ color components in controls of $\mathrm{m}$. Longissimus dorsi and $\mathrm{m}$. Semimembranosus was determined (Table. 4). Both phytonutrients did not have a one-way effect on the color characteristics of the frozen lamb muscles. Compared to the controls $\mathrm{C}$ on $1 \mathrm{~d}$ post mortem, the total color difference $(\Delta \mathrm{E})$ in samples $\mathrm{DQ}$ is bigger compared to that for samples DDRP. After $365 \mathrm{~d}$ of storage at $-18^{\circ} \mathrm{C}$ the trend is reversed. The $\Delta \mathrm{E}$ in samples DQ is significantly smaller compared to samples DDRP in both muscles. The myoglobin is responsible for the meat color stability after freezing and thawing [22], because it denatures and the iron heme is oxidized which leads to the formation of gray-brown metmyoglobin. One-day post mortem the enzyme system with metmyoglobin reductase activity (MRA) is very active and the formed metmyoglobin is rapidly reduced to deoxymyoglobin and oxidized back to oxymyoglobin. After $365 \mathrm{~d}$ storage at $-18^{\circ} \mathrm{C}$ MRA is rapidly inactivated by the mitochondrial cytoplasm enzyme $\beta$-hydroxyacyl CoA-dehydrogenase (HADH). Its activity decreases as a result, metmyoglobin is formed on the surface of the meat. Therefore, meat oxidation is a chain autocatalytic reaction initiated by lipid hydroperoxides that is transferred to the myoglobin fraction [29]. It was found 
the stabilization of the brightness $\left(\mathrm{L}^{*}\right)$ and the red $\left(\mathrm{a}^{*}\right)$ component of the color and contributes to $(\mathrm{p} \leq 0.05)$ an increase in the yellow ( $\left.b^{*}\right)$ component by approx. 1.5 times in samples DDRP of frozen m. Longissimus dorsi (365 d). For comparison, in the samples DQ a significant increase of the brightness $\left(\mathrm{L}^{*}\right)$ by $13 \%$ of the red $\left(\mathrm{a}^{*}\right)$ component by $6 \%$ and of the yellow $\left(b^{*}\right)$ component of the color -2.7 times was found. Samples DDRP of frozen m. Semimembranosus (365 d) showed $(\mathrm{p} \leq 0.05)$ a decrease in the brightness $\left(\mathrm{L}^{*}\right)$ by more than $15 \%$, in the red $\left(\mathrm{a}^{*}\right)$ component by a little over 3\% and in the yellow (b*) component of the color by about 32\% (Table 4). In parallel, in samples DQ of frozen m. Semimembranosus ( $365 \mathrm{~d}$ ) the color brightness $\left(\mathrm{L}^{*}\right)$ is reduced by $2 \%$ only, the red $\left(\mathrm{a}^{*}\right)$ component of the color by $3.5 \%$ and the yellow $\left(\mathrm{b}^{*}\right)$ component is increased 1.77 times (Table 4 ).

In summary, the addition of the DQ [6] or the rich in polyphenolic components DDRP [7] to the lamb's feed leads to divergent changes in color characteristics in both studied muscles after their 365 days of frozen storage. The total color difference in samples DQ is smaller than in samples DDRP.

\section{Biogenic amines}

The levels of biogenic amines are lower than the limit of detection (LoD $-10 \mathrm{mg} / \mathrm{kg}$ ) of the analytical method in all tested samples (Table 5). These results indicate that a major role in limiting the formation of biogenic amines in lamb muscle and adipose tissues is played by the freezing factor and not by the addition of DQ or DDRP to lambs' feed.

\section{Microbiological changes}

Compared to control samples, the addition of DQ or DDRP to lambs' feed did not lead to significant changes in psychrotrophic bacterial count (PBC) and total combined yeasts and molds count (TYMC) in frozen lamb $\mathrm{m}$. Longissimus dorsi, m. Semimembranosus and perirenal adipose tissue (Table 6). On the other hand, samples DQ and DDRP show a lower APC, more pronounced in samples DDRP. Regardless of the relatively small doses and the relatively short period of application of phytonutrients as feed supplements their intake has a certain bactericidal effect after one year of frozen storage of lamb m. Longissimus dorsi. Our results contradict the opinion of [22] who believe that during freezing microorganisms fall into a latent state which effectively stops microbial growth. According to Leygonie et al. [22] it is possible for aerobic microflora to regain their activity during the air defrosting of the meat as it is a much slower process than freezing. Our results (Table 6) show the absence of molds and yeast in the frozen lamb samples after $365 \mathrm{~d}$ of frozen storage and do not confirm the above hypothesis. On the contrary, the increase in the PBC found in our study after $365 \mathrm{~d}$ of lamb frozen storage was in line with the results reported by Vieira et al. [30] found after $90 \mathrm{~d}$ of frozen storage of aged beef. Moreover, compared to control sample, samples DQ and DDRP showed a slightly higher number of PBC. There is an indirect evidence that flavonoids help the animal organism build an integrated antioxidant system by preventing the harmful effects of free radicals. Antioxidant compounds imported with phytonutrients are likely to affect psychrotrophic bacteria in muscle tissue in a similar way.

\section{Conclusions}

The supplementation of the lambs' diet with the addition of $7.5 \mathrm{mg} \mathrm{DQ} / \mathrm{kg} / \mathrm{d}$ and resp. of $545 \mathrm{mg}$ dry distilled rose petals $/ \mathrm{kg} / \mathrm{d}$ did not uniquely affect the quality of the quick-frozen m. Longissimus dorsi, m. Semimembranosus and perirenal adipose tissue after $365 \mathrm{~d}$ of storage at $-18^{\circ} \mathrm{C}$. Changes in POV, biogenic amines, PBC and TYMC are not 
affected by the addition of phytonutrients to lambs' feed but mainly by the factor of one-year frozen storage. The color characteristics change differently in both muscles. Compared to controls, the total color difference $(\Delta \mathrm{E})$ in the addition of DDRP was smaller than the one of DQ. Supplementing the lambs' diet with phytonutrient-rich polyphenols contributes to some reduction in APC, $\alpha$-aminoacidic nitrogen, protein carbonyls and TBARS but with small amplitudes. It also reduces the content of SFA at the expense of increasing MUFA. These trends are more pronounced in $\mathrm{m}$. Longissimus dorsi from lambs fed with feed supplemented with $545 \mathrm{mg} \mathrm{DDRP} / \mathrm{kg} / \mathrm{d}$. Additional studies are needed to clarify the nature of the interactions between the factors breed, age, temperature and shelf life as well as feeding conditions, including to answer the question of whether the use of higher doses of DDRP or DQ as dietary supplements in small ruminants will be able to provide a more pronounced inhibitory effect on lipid oxidation and fatty acid composition of lamb muscles and fats? When determining the doses of these phytonutrients in these future studies it should be taken into account that the antioxidant activity of polyphenols, resp. of flavonoids in biological systems in vivo, undergoes metabolic transformation and their very high doses can act as prooxidants and inhibit various enzymes and the absorption of certain minerals and vitamins.

\section{Acknowledgements}

314

This work was supported by the Bulgarian National Science Fund (BNSF), Ministry of Education and Science of Republic of Bulgaria of state contract No DN 06/8 of 17 December 2016 "Study of the mechanism of biological active compounds of plant origin accumulation in the organism of Bulgarian breed agricultural animals and their impact on the meat quality as a natural functional food".

\section{Conflict of interest}

The authors declare that they have no conflict of interest.

\section{Ethical approval}

323 The experiments were performed with 30 clinically healthy male lambs aged 65 days, equal in live weight. The experiments were carried out in accordance with the recommendations of the European Convention for the Protection of Vertebrate Animals Used for Experimental and Other Scientific Purposes, Regulation (EC) No. 1099/2009 of the Council, Recommendation 2007/526/EC of the Commission and the Law on Veterinary Medicine in Bulgaria. The experiment was coordinated and approved by the Bulgarian Commission on Scientific Ethics, in compliance with Council Directive 2010/63/EU.

\section{Informed consent}

Informed consent is not applicable.

\section{Data availability}

334 The data that support the findings of the study are available form the corresponding author upon reasonable request. 


\section{References}

1. Coombs CEO, Holman BWB, Friend MA, Hopkins DL (2017) Long-term red meat preservation using chilled and frozen storage combinations: A review. Meat Sci, 125: 84-94

2. Muela E, Monge P, Sañudo C, Campo MM, Beltrán JA (2016) Sensory quality of lamb following long-term frozen storage. Meat Sci, 114: 32-37

3. Pinheiro RSB, Francisco CL, Lino DM, Borbad H (2019) Meat quality of Santa Inês lamb chilled-then-frozen storage up to 12 months. Meat Sci, 148: $72-78$

4. Oh J, Wall EH, Bravo DM, Hristov AN (2016) 1036 Phytonutrients as additives in ruminants: the unexpected target organ. J Anim Sci, 2016, 94: 496-497

5. Surai PF (2014) Polyphenol compounds in the chicken/animal diet: from the past to the future. J Anim Physiol Anim Nutr, 98: 19-31

6. Fomichev Y, Nikanova L, Lashin A (2016) The effectiveness of using dihydroquercetin (taxifolin) in animal husbandry, poultry and apiculture for prevention of metabolic disorders, higher antioxidative capacity, better resistance and realization of a productive potential of organism. Agric \& Food, 4: 140-159

7. Dragoev SD, Vlahova-Vangelova D, Balev D, Bozhilov D, Dagnon S (2021) Valorization of waste by-products of rose oil production as feedstuff phytonutrients. Bulg J Agric Sci, 27: 209-219

8. Baydar NG, Baydar H (2013) Phenolic compounds, antiradical activity and antioxidant capacity of oil-bearing rose (Rosa damascena Mill.) extracts. Ind Crop and Prod, 41: 375-380

9. Ivanova S, Nakev J, Nikolova T, Vlahova-Vangelova D, Balev D, Dragoev S, Gerrard D, Grozlekova L, Tashkova D (2021). Effect of new livestock feeds' phytonutrients on productivity, carcass composition and meat quality in pigs. Bulg J Agric Sci, 27: 1178-1186

10. Stancheva NZ, Nakev JL, Vlahova-Vangelova DB, Balev DK, Dragoev SG (2021) Impact of Siberian larch dihydroquercetin or dry distilled rose petals as feed supplements on lamb's growth performance, carcass characteristics and blood count parameters. Iran J Appl Anim Sci, 11: 339-350

11. Garrido R, Domínguez R, Lorenzo JM, Franco I, Carballo J (2012) Effect of the length of salting time on the proteolytic changes in dry-cured lacón during ripening and on the sensory characteristics of the final product. Food Control, 25: 789-796

12. Mercier Y, Gatellier P, Renerre M (2004) Lipid and protein oxidation in vitro, and antioxidant potential in meat from Charolais cows finished on pasture or mixed diet. Meat Sci, 66: 467-473

13. Bligh EG, Dyer WJ (1959) A rapid method of total lipid extraction and purification. Can J Biochem Physiol, 37: 911-917

14. ISO 660:2009 (2009) Animal and vegetable fats and oils - Determination of acid value and acidity. https://www.iso.org/standard/44879.html

15. Botsoglou NA, Fletouris DJ, Papageorgiou CE, Vassilopoulos VN, Mantis AJ, Trakatellis AG (1994) Rapid sensitive and specific thiobarbituric acid method for measuring lipid peroxidation in animal tissue, food and feedstuff samples. J Agric Food Chem, 42: 1931-1937 
16. Schmedes AV, Hølmer G (1989) A new thiobarbituric acid (TBA) method for determining free malondialdehyde (MDA) and hydroperoxides selectively as a measure of lipid peroxidation. J Am Oil Chem Soc, 66: 813-817

17. ISO 12966-2:2011 (2011) Animal and vegetable fats and oils - Gas chromatography of fatty acid methyl esters - Part 2: Preparation of methyl esters of fatty acids. International Organization for Standardization: Geneva, Switzerland. https://www.iso.org/standard/43172.html

18. ISO 12966-1:2014 (2014) Animal and vegetable fats and oils - Gas chromatography of fatty acid methyl esters - Part 1: Guidelines on modern gas chromatography of fatty acid methyl esters. International Organization for Standardization: Geneva, Switzerland. https://www.iso.org/standard/52294.html

19. Karp S, Wyrwisz J, Kurek MA (2020) The impact of different levels of oat b-glucan and water on gluten free cake rheology and physicochemical characterization. J Food Sci Technol, 57: 3628-3638 https://doi.org/10.1007/s13197-020-04395-5

20. Tkacz K, Modzelewska-Kapituła M, Więk A, Nogalski Z (2020) The applicability of total color difference $\Delta \mathrm{E}$ for determining the blooming time in Longissimus lumborum and Semimembranosus muscles from HolsteinFriesian bulls at different ageing times. Appl Sci, 10: 8215 https://doi.org/10.3390/app10228215

21. ISO 4833:2003 (2003) Microbiology of food and animal feeding stuffs - Horizontal method for the enumeration of microorganisms - Colony-count technique at 30 degrees C. https://www.iso.org/standard/34524.html

22. Leygonie C, Britz TJ, Hoffman LC (2012) Impact of freezing and thawing on the quality of meat: Review. Meat Sci, 91: 93-98

23. Benjakul S, Visessanguan W, Thongkaew C, Tanaka M (2003) Comparative study on physicochemical changes of muscle proteins from some tropical fish during frozen storage. Food Res Int, 36: 787-795

24. Xue M, Huang F, Huang M, Zhou G (2013) Influence of oxidation on myofibrillar proteins degradation from bovine via $\mu$-calpain. Food Chem, 134: 106-112

25. Traore S, Aubry L, Gatellier P, Przybylski W, Jaworska D, Kajak-Siemaszko K, Santé-Lhoutelliera V (2012) Effect of heat treatment on protein oxidation in pig meat. Meat Sci, 91: 14-21

26. Yi G, Haug A, Nyquist NF, Egelandsdal B (2013) Hydroperoxide formation in different lean meats. Food Chem, 141: 2656-2665

27. Leygonie C, Britz TJ, Hoffman LC (2011) Oxidative stability of previously frozen ostrich M. iliofibularis packaged under different modified atmospheric conditions. Int J Food Sci Technol, 46: 1171-1178

28. Banskalieva T, Sahlu V, Goetsch AL (2000) Fatty acid composition of goat muscles and fat depots: a review. Small Rum Res, 37: 255-268

29. Zhou F, Jongberg S, Zhao M, Sun W, Skibsted LH (2016) Iron (II) initiation of lipid and protein oxidation in pork: The role of oxymyoglobin. J Agric Food Chem, 2016, 64: 4618-4626 and length of storage) on microbial and sensory quality of rustic crossbred beef at different stages of aging. Meat Sci, 83: 398-404 


\section{$411 \quad$ List of tables titles/legends}

412

413 Table 1. Changes in muscle protein fraction affected by feed supplementation with phytonutrients and one-year

414 (365d) of storage at $-18^{\circ} \mathrm{C}$

415 Table 2. Changes in the lipid fraction of muscle and perirenal adipose tissue affected by feed supplementation with 416 phytonutrients and one-year $(365 \mathrm{~d})$ of frozen storage at $-18^{\circ} \mathrm{C}$

417 Table 3. Changes in the fatty acid composition of total lipids from muscle and perirenal adipose tissue affected by

418 feed supplementation with phytonutrients and one-year (365 d) of frozen storage at $-18^{\circ} \mathrm{C}$

419 Table 4. Changes in the color characteristics of $\mathrm{m}$. Longissimus dorsi and $\mathrm{m}$. Semimembranosus affected by feed 420 supplementation with phytonutrients and one-year $(365 \mathrm{~d})$ of frozen storage at $-18^{\circ} \mathrm{C}$

421 Table 5. Presence of biogenic amines after one year $(365 \mathrm{~d})$ of frozen storage at $-18^{\circ} \mathrm{C}$ obtained from animals fed with

422 phytonutrient supplements

423 Table 6. Microbiological status of $\mathrm{m}$. Longissimus dorsi after one year ( $365 \mathrm{~d})$ of frozen storage at $-18^{\circ} \mathrm{C}$ obtained 424 from animals fed with phytonutrient supplement 
Table 1. Changes in muscle protein fraction affected by feed supplementation with phytonutrients and one-year (365d) of storage at $-18^{\circ} \mathrm{C}$

\section{Lamb tissue}

m. Longissimus dorsi

m. Semimembranosus

\section{Parameters}

$\mathbf{C}$

DQ

DDRP

C

DQ

DDRP

$\alpha$-aminoacidic nitrogen,

mg Leu/g - $1 \mathrm{~d}$

$2.10 \pm 0.08^{*}$

$2.31 \pm 0.02^{*}$

$2.43 \pm 0.03^{*}$

$2.10 \pm 0.08^{*}$

$2.50 \pm 0.01^{*}$

$2.34 \pm 0.03^{*}$

$\alpha$-aminoacidic nitrogen,

$\mathrm{mg} \mathrm{Leu/g} \mathrm{-} 365 \mathrm{~d}$

$9.94 \pm 0.04^{*}$

$8.46 \pm 0.05^{*}$

$7.43 \pm 0.07^{*}$

$10.36 \pm 0.01^{*}$

$9.24 \pm 0.18^{*}$

$9.45 \pm 0.11^{*}$

Protein carbonyls, nmol

DNPH/mg protein - $1 \mathrm{~d}$

$0.0469 \pm 0.0008^{*}$

$0.0470 \pm 0.0012^{*}$

$0.0319 \pm 0.0005^{*}$

$0.0469 \pm 0.0011^{*}$

$0.0469 \pm 0.0008^{*}$

$0.0488 \pm 0.0006^{*}$

Protein carbonyls, nmol

DNPH/mg protein $-365 \mathrm{~d}$

$0.0952 \pm 0.0004^{*} \quad 0.0954 \pm 0.0007^{*}$

$0.0649 \pm 0.0007^{*}$

$0.1083 \pm 0.0009^{*}$

$0.1168 \pm 0.0008^{*}$

$0.2004 \pm 0.0028^{*}$

C - control group lambs fed with ground alfalfa + pelleted compound feed

DQ - experimental groups lambs fed with the same diet supplemented with addition of $7.5 \mathrm{mg} \mathrm{DQ} / \mathrm{kg}$ life weight/d

DDRP - experimental groups lambs fed with the same diet supplemented with addition of $545 \mathrm{mg}$ dry distilled rose petals (DDRP)/kg life weight/d

Results are presented as Means \pm Standard error of the means (SEM); $n=10$

* - indicates significance $(\mathrm{p} \leq 0.05)$ of both factors (type of diet and time of frozen storage) and their interaction; 
Table 2. Changes in the lipid fraction of muscle and perirenal adipose tissues affected by feed supplementation with phytonutrients and one-year ( $365 \mathrm{~d})$ of frozen storage at $-18^{\circ} \mathrm{C}$

\begin{tabular}{|c|c|c|c|c|c|c|c|c|c|}
\hline \multirow{2}{*}{$\begin{array}{l}\text { Lamb tissue } \\
\text { Parameters }\end{array}$} & \multicolumn{3}{|c|}{ m. Longissimus dorsi } & \multicolumn{3}{|c|}{ m. Semimembranosus } & \multicolumn{3}{|c|}{ Perirenal adipose tissue } \\
\hline & $\mathbf{C}$ & DQ & DDRP & $\mathbf{C}$ & DQ & DDRP & $\mathbf{C}$ & DQ & DDRP \\
\hline $\begin{array}{l}\text { cid value, } \\
\mathrm{g} \mathrm{KOH} / \mathrm{g}-1 \mathrm{~d}\end{array}$ & $4.41 \pm 0.05^{*}$ & $3.80 \pm 0.02^{*}$ & $3.64 \pm 0.03^{*}$ & $4.85 \pm 0.04^{*}$ & $4.65 \pm 0.05^{*}$ & $2.85 \pm 0.02^{*}$ & $2.25 \pm 0.02^{*}$ & $2.09 \pm 0.01^{*}$ & $1.92 \pm 0.01^{*}$ \\
\hline $\begin{array}{l}\text { cid value, } \\
\mathrm{g} \mathrm{KOH} / \mathrm{g}-365 \text { d }\end{array}$ & $5.53 \pm 0.04^{*}$ & $4.59 \pm 0.03^{*}$ & $5.04 \pm 0.03^{*}$ & $5.86 \pm 0.03^{*}$ & $5.44 \pm 0.02^{*}$ & & $3.84 \pm 0.03^{*}$ & $3.30 \pm 0.03^{*}$ & $3.98 \pm 0.02 *$ \\
\hline $\begin{array}{l}\text { Peroxide value, } \\
\mu \mathrm{eqO}_{2} / \mathrm{g} \text { lipids - } 1 \mathrm{~d}\end{array}$ & $0.111 \pm 0.002^{*}$ & $0.119 \pm 0.001^{*}$ & $0.112 \pm 0.002^{*}$ & $0.126 \pm 0.001^{*}$ & $0.116 \pm 0.001^{*}$ & & $0.108 \pm 0.001^{*}$ & $0.105 \pm 0.001^{*}$ & $0.105 \pm 0.001^{*}$ \\
\hline $\begin{array}{l}\text { Peroxide value, } \\
\mu \text { eqO } \mathrm{O}_{2} / \mathrm{g} \text { lipids- } 365 \mathrm{~d}\end{array}$ & $0.064 \pm 0.001^{*}$ & $0.074 \pm 0.001^{*}$ & $0.071 \pm 0.001 *$ & $0.123 \pm 0.001 *$ & $0.075 \pm 0.001^{*}$ & $0.074 \pm 0.001^{*}$ & $0.074 \pm 0.001^{* *}$ & $0.072 \pm 0.002^{* *}$ & $0.073 \pm 0.001^{* *}$ \\
\hline $\begin{array}{l}\text { TBARS, } \\
\mathrm{mg} \text { MDA/kg - } 1 \mathrm{~d}\end{array}$ & $0.43 \pm 0.011^{*}$ & $0.34 \pm 0.022^{*}$ & $0.64 \pm 0.025^{*}$ & $0.70 \pm 0.042^{*}$ & $0.59 \pm 0.003^{*}$ & $0.53 \pm 0.042^{*}$ & $0.24 \pm 0.013^{*}$ & $0.21 \pm 0.010^{*}$ & $0.31 \pm 0.012^{*}$ \\
\hline $\begin{array}{l}\text { TBARS, } \\
\text { mg MDA/kg -365 d }\end{array}$ & $0.20 \pm 0.012^{*}$ & $0.20 \pm 0.004^{*}$ & $0.10 \pm 0.008^{*}$ & $0.41 \pm 0.037^{*}$ & $0.15 \pm 0.007^{*}$ & $0.19 \pm 0.007^{*}$ & $0.54 \pm 0.009^{*}$ & $0.33 \pm 0.012^{*}$ & $0.79 \pm 0.007^{*}$ \\
\hline
\end{tabular}

C - control group lambs fed with ground alfalfa + pelleted compound feed

DQ - experimental groups lambs fed with the same diet supplemented with addition of $7.5 \mathrm{mg} D Q / \mathrm{kg}$ life weight/d

DDRP - experimental groups lambs fed with the same diet supplemented with addition of $545 \mathrm{mg}$ dry distilled rose petals (DDRP)/kg life weight/d

Results are presented as Means \pm Standard error of the means (SEM); $\mathrm{n}=10$

* - indicates significance $(\mathrm{p} \leq 0.05)$ of both factors (type of diet and time of frozen storage) and their interaction;

** - indicates significance $(\mathrm{p} \leq 0.05)$ for the factor time of storage only; 
Table 3. Changes in the fatty acid composition of total lipids from muscle and perirenal adipose tissues affected by feed supplementation with phytonutrients and one-year (365 d) of frozen storage at $-18^{\circ} \mathrm{C}$

\begin{tabular}{|c|c|c|c|c|c|c|c|c|c|}
\hline \multirow[b]{2}{*}{ Fatty acids } & Lamb tissue & \multicolumn{2}{|c|}{ m. Longissimus dorsi } & \multicolumn{3}{|c|}{ m. Semimembranosus } & \multicolumn{3}{|c|}{ Perirenal adipose tissue } \\
\hline & $\mathbf{C}$ & DQ & DDRP & $\mathbf{C}$ & DQ & DDRP & $\mathbf{C}$ & DQ & DDRP \\
\hline $\bar{C} 12: 0-1 \mathrm{~d}$ & $0.2 \pm 0.01$ & $0.1 \pm 0.01$ & $0.2 \pm 0.02$ & $0.1 \pm 0.01$ & $0.5 \pm 0.02$ & $0.6 \pm 0.03$ & $0.3 \pm 0.01$ & $0.5 \pm 0.01$ & $0.9 \pm 0.01$ \\
\hline C $12: 0-365 d$ & $0.2 \pm 0.02$ & $0.4 \pm 0.01$ & $0.1 \pm 0.03$ & $0.1 \pm 0.01$ & $0.1 \pm 0.02$ & $0.3 \pm 0.01$ & $0.1 \pm 0.02$ & $0.3 \pm 0.01$ & $0.5 \pm 0.02$ \\
\hline C $14: 0-1 d$ & $2.5 \pm 0.01$ & $5.8 \pm 0.01$ & $3.4 \pm 0.01$ & $2.8 \pm 0.02$ & $5.1 \pm 0.01$ & $4.8 \pm 0.01$ & $2.9 \pm 0.01$ & $4.3 \pm 0.01$ & $6.2 \pm 0.01$ \\
\hline C $14: 0-365 d$ & $4.1 \pm 0.02$ & $4.4 \pm 0.02$ & $2.3 \pm 0.02$ & $5.2 \pm 0.01$ & $3.0 \pm 0.01$ & $3.6 \pm 0.02$ & $3.0 \pm 0.03$ & $3.7 \pm 0.02$ & $5.2 \pm 0.01$ \\
\hline C $15: 0-1 d$ & $0.1 \pm 0.03$ & $0.7 \pm 0.02$ & $0.4 \pm 0.01$ & $0.4 \pm 0.01$ & $0.5 \pm 0.03$ & $0.4 \pm 0.02$ & traces & $0.1 \pm 0.01$ & $0.1 \pm 0.01$ \\
\hline C $15: 0-365 d$ & $0.4 \pm 0.01$ & $0.5 \pm 0.01$ & $0.4 \pm 0.02$ & $0.6 \pm 0.02$ & $0.9 \pm 0.01$ & $1.6 \pm 0.01$ & $0.9 \pm 0.01$ & $0.4 \pm 0.02$ & $0.7 \pm 0.03$ \\
\hline C $16: 0-1 d$ & $23.2 \pm 0.02$ & $34.4 \pm 0.01$ & $25.3 \pm 0.01$ & $22.5 \pm 0.02$ & $29.3 \pm 0.01$ & $28.6 \pm 0.02$ & $19.0 \pm 0.01$ & $23.2 \pm 0.01$ & $29.8 \pm 0.02$ \\
\hline C $16: 0-365 d$ & $27.4 \pm 0.03$ & $29.2 \pm 0.02$ & $24.8 \pm 0.01$ & $37.2 \pm 0.02$ & $27.6 \pm 0.03$ & $31.5 \pm 0.01$ & $26.3 \pm 0.01$ & $24.1 \pm 0.02$ & $28.1 \pm 0.02$ \\
\hline C $16: 1-1 d$ & $1.4 \pm 0.02$ & $1.9 \pm 0.01$ & $2.0 \pm 0.02$ & $1.4 \pm 0.01$ & $2.1 \pm 0.03$ & $1.5 \pm 0.01$ & $0.9 \pm 0.02$ & $1.6 \pm 0.02$ & $1.6 \pm 0.03$ \\
\hline C $16: 1-365 d$ & $1.6 \pm 0.01$ & $1.4 \pm 0.01$ & $1.3 \pm 0.03$ & $1.8 \pm 0.02$ & $2.4 \pm 0.01$ & $2.5 \pm 0.02$ & $1.4 \pm 0.01$ & $1.1 \pm 0.02$ & $2.4 \pm 0.01$ \\
\hline C 17:0 - 1 d & $1.4 \pm 0.02$ & $1.7 \pm 0.01$ & $1.4 \pm 0.01$ & $1.3 \pm 0.01$ & $1.4 \pm 0.01$ & $1.0 \pm 0.02$ & $1.6 \pm 0.01$ & $2.4 \pm 0.02$ & $1.3 \pm 0.01$ \\
\hline C $17: 0-365 d$ & $1.8 \pm 0.02$ & $1.7 \pm 0.01$ & $2.0 \pm 0.02$ & $1.9 \pm 0.01$ & $2.5 \pm 0.02$ & $2.3 \pm 0.02$ & $2.2 \pm 0.01$ & $1.8 \pm 0.02$ & $1.7 \pm 0.02$ \\
\hline C $17: 1-1 d$ & $0.5 \pm 0.01$ & $0.5 \pm 0.02$ & $0.8 \pm 0.01$ & $0.5 \pm 0.02$ & $0.6 \pm 0.01$ & $0.7 \pm 0.01$ & $0.3 \pm 0.02$ & $0.5 \pm 0.01$ & $0.5 \pm 0.02$ \\
\hline C $17: 1-365 d$ & $0.8 \pm 0.01$ & $0.8 \pm 0.02$ & $0.9 \pm 0.02$ & $0.9 \pm 0.02$ & $1.7 \pm 0.01$ & $1.8 \pm 0.01$ & $0.8 \pm 0.01$ & $0.5 \pm 0.01$ & $0.9 \pm 0.01$ \\
\hline C $18: 0-1 d$ & $13.5 \pm 0.02$ & $15.5 \pm 0.01$ & $12.7 \pm 0.02$ & $15.1 \pm 0.03$ & $13.2 \pm 0.03$ & $14.5 \pm 0.02$ & $21.7 \pm 0.01$ & $23.5 \pm 0.01$ & $16.8 \pm 0.03$ \\
\hline C $18: 0-365 d$ & $10.8 \pm 0.02$ & $16.6 \pm 0.02$ & $6.2 \pm 0.03$ & $6.0 \pm 0.01$ & $6.4 \pm 0.01$ & $1.7 \pm 0.03$ & $8.2 \pm 0.02$ & $3.4 \pm 0.03$ & $7.5 \pm 0.01$ \\
\hline C $18: 1-1 d$ & $48.8 \pm 0.01$ & $33.4 \pm 0.03$ & $47.9 \pm 0.01$ & $49.1 \pm 0.03$ & $40.1 \pm 0.03$ & $42.5 \pm 0.03$ & $45.2 \pm 0.01$ & $36.7 \pm 0.03$ & $40.6 \pm 0.03$ \\
\hline C $18: 1-365 d$ & $51.7 \pm 0.03$ & $42.8 \pm 0.03$ & $61.4 \pm 0.03$ & $45.5 \pm 0.01$ & $53.7 \pm 0.02$ & $52.6 \pm 0.01$ & $56.4 \pm 0.03$ & $63.1 \pm 0.01$ & $49.1 \pm 0.01$ \\
\hline C $18: 2-1 d$ & $7.1 \pm 0.02$ & $3.9 \pm 0.01$ & $4.9 \pm 0.01$ & $5.9 \pm 0.01$ & $5.4 \pm 0.02$ & $4.6 \pm 0.02$ & $7.1 \pm 0.03$ & $5.9 \pm 0.01$ & $0.8 \pm 0.01$ \\
\hline C $18: 2-365 d$ & $0.7 \pm 0.01$ & $1.2 \pm 0.01$ & $0.3 \pm 0.03$ & $0.2 \pm 0.03$ & $0.5 \pm 0.01$ & traces & traces & $0.7 \pm 0.02$ & $3.2 \pm 0.01$ \\
\hline C $18: 3-1 d$ & $0.4 \pm 0.02$ & $1.6 \pm 0.03$ & $0.3 \pm 0.02$ & $0.6 \pm 0.01$ & $0.9 \pm 0.01$ & $0.1 \pm 0.02$ & $0.6 \pm 0.01$ & $0.8 \pm 0.02$ & $0.6 \pm 0.02$ \\
\hline C $18: 3-365 d$ & $0.1 \pm 0.02$ & $0.1 \pm 0.01$ & traces & traces & traces & $0.1 \pm 0.02$ & traces & traces & $0.1 \pm 0.01$ \\
\hline C 20:0 - $1 \mathrm{~d}$ & NF & NF & NF & NF & NF & NF & NF & NF & NF \\
\hline C $20: 0-365 d$ & NF & $\mathrm{NF}$ & NF & $\mathrm{NF}$ & NF & $0.1 \pm 0.01$ & NF & NF & $\mathrm{NF}$ \\
\hline C $20: 2-1 d$ & NF & NF & NF & NF & NF & NF & NF & NF & NF \\
\hline C $20: 2-365 d$ & $0.1 \pm 0.02$ & traces & $0.1 \pm 0.01$ & $0.1 \pm 0.01$ & $0.2 \pm 0.01$ & $0.1 \pm 0.02$ & traces & $0.6 \pm 0.01$ & traces \\
\hline
\end{tabular}


Table 3 - continued

\begin{tabular}{|c|c|c|c|c|c|c|c|c|c|}
\hline $\begin{array}{l}\text { Saturated fatty acids SFA - } \\
1 \mathrm{~d}\end{array}$ & $41.7 \pm 0.03^{*}$ & $58.6 \pm 0.01 *$ & $44.0 \pm 0.02 *$ & $42.4 \pm 0.01 *$ & $50.7 \pm 0.03^{*}$ & $50.5 \pm 0.02^{*}$ & $45.7 \pm 0.01^{*}$ & $54.3 \pm 0.01 *$ & $55.7 \pm 0.01 *$ \\
\hline $\begin{array}{l}\text { Saturated fatty acids SFA- } \\
365 \mathrm{~d}\end{array}$ & $44.9 \pm 0.01 *$ & $53.1 \pm 0.03^{*}$ & $35.9 \pm 0.01 *$ & $51.2 \pm 0.02^{*}$ & $40.6 \pm 0.03^{*}$ & $41.5 \pm 0.01^{*}$ & $40.9 \pm 0.01 *$ & $33.7 \pm 0.01 *$ & $44.0 \pm 0.03 *$ \\
\hline $\begin{array}{l}\text { Unsaturated fatty acids UFA - } \\
1 \text { d }\end{array}$ & $58.3 \pm 0.01 *$ & $41.4 \pm 0.03 *$ & $56.0 \pm 0.01^{*}$ & $57.6 \pm 0.01 *$ & $49.3 \pm 0.01 *$ & $49.5 \pm 0.02^{*}$ & $54.3 \pm 0.03^{*}$ & $45.7 \pm 0.01^{*}$ & $44.3 \pm 0.01 *$ \\
\hline $\begin{array}{l}\text { Unsaturated fatty acids UFA - } 365 \\
\text { d }\end{array}$ & $55.1 \pm 0.01 *$ & $46.8 \pm 0.03^{*}$ & $64.1 \pm 0.01^{*}$ & $48.8 \pm 0.02^{*}$ & $59.4 \pm 0.01 *$ & $58.5 \pm 0.01 *$ & $59.1 \pm 0.01^{*}$ & $66.3 \pm 0.01^{*}$ & $56.0 \pm 0.02 *$ \\
\hline $\begin{array}{l}\text { Monounsaturated fatty acids MUFA- } \\
1 d\end{array}$ & $50.8 \pm 0.01^{*}$ & $35.9 \pm 0.01^{*}$ & $50.8 \pm 0.03^{*}$ & $51.1 \pm 0.01^{*}$ & $43.0 \pm 0.01^{*}$ & $44.8 \pm 0.01^{*}$ & $46.6 \pm 0.01^{*}$ & $39.0 \pm 0.03^{*}$ & $42.9 \pm 0.01^{*}$ \\
\hline $\begin{array}{l}\text { Monounsaturated fatty acids } \\
\text { MUFA - 365d }\end{array}$ & $54.2 \pm 0.02^{*}$ & $45.6 \pm 0.01^{*}$ & $63.7 \pm 0.02^{*}$ & $48.5 \pm 0.03^{*}$ & $58.7 \pm 0.01^{*}$ & $58.3 \pm 0.01^{*}$ & $59.1 \pm 0.03^{*}$ & $65.0 \pm 0.02^{*}$ & $52.7 \pm 0.01^{*}$ \\
\hline $\begin{array}{l}\text { Polyunsaturated fatty acids } \\
\text { PUFA }-1 d\end{array}$ & $7.5 \pm 0.01^{*}$ & $5.5 \pm 0.01^{*}$ & $5.2 \pm 0.03^{*}$ & $6.5 \pm 0.01^{*}$ & $6.3 \pm 0.01^{*}$ & $4.7 \pm 0.01^{*}$ & $7.7 \pm 0.01^{*}$ & $6.7 \pm 0.03^{*}$ & $1.4 \pm 0.01^{*}$ \\
\hline $\begin{array}{l}\text { Polyunsaturated fatty acids } \\
\text { PUFA }-365 d\end{array}$ & $0.9 \pm 0.01^{*}$ & $1.3 \pm 0.01^{*}$ & $0.4 \pm 0.01^{*}$ & $0.3 \pm 0.01^{*}$ & $0.7 \pm 0.01^{*}$ & $0.2 \pm 0.01^{*}$ & $N F^{*}$ & $1.3 \pm 0.01^{*}$ & $3.3 \pm 0.01^{*}$ \\
\hline
\end{tabular}

C - control group lambs fed with ground alfalfa + pelleted compound feed

DQ - experimental groups lambs fed with the same diet supplemented with addition of $7.5 \mathrm{mg}$ DQ/kg life weight $/ \mathrm{d}$

DDRP - experimental groups lambs fed with the same diet supplemented with addition of $545 \mathrm{mg}$ dry distilled rose petals (DDRP)/kg life weight/d

Results are presented as Means \pm Standard error of the means (SEM); $\mathrm{n}=10$

* - indicates significance $(\mathrm{p} \leq 0.05)$ of both factors (type of diet and time of frozen storage) and their interaction;

Traces - below the limit of detection (LoD)

NF - not found; 
Table 4. Changes in muscle color characteristics affected by feed supplementation with phytonutrients and one-year (365d) of storage at $-18^{\circ} \mathrm{C}$

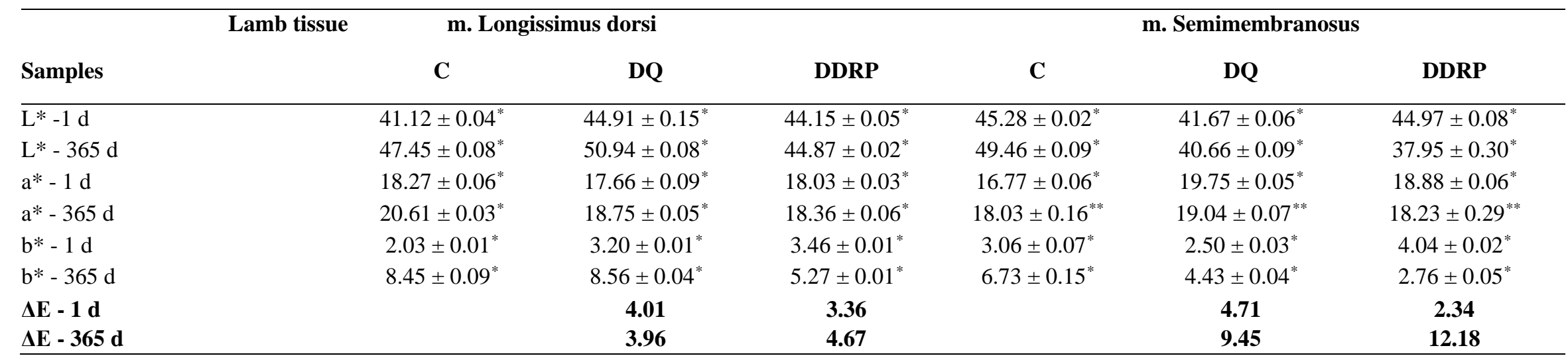

C - control group lambs fed with ground alfalfa + pelleted compound feed

DQ - experimental groups lambs fed with the same diet supplemented with addition of $7.5 \mathrm{mg} \mathrm{DQ} / \mathrm{kg}$ life weight $/ \mathrm{d}$

DDRP - experimental groups lambs fed with the same diet supplemented with addition of $545 \mathrm{mg}$ dry distilled rose petals (DDRP)/kg life weight/d Results are presented as Means \pm Standard error of the means (SEM); $n=10$

* - indicates significance $(\mathrm{p} \leq 0.05)$ of both factors (type of diet and time of frozen storage) and their interaction;

$* *$ - indicates significance $(\mathrm{p} \leq 0.05)$ of factors type of diet and interaction between the factors, excluding the time of storage; 
Table 5. Presence of biogenic amines after one year ( $365 \mathrm{~d})$ of frozen storage at $-18^{\circ} \mathrm{C}$ obtained from animals fed with phytonutrient supplements

Lamb tissue

m. Longissimus dorsi

m. Semimembranosus

Perirenal adipose tissue

\begin{tabular}{|c|c|c|c|c|c|c|c|c|c|}
\hline Samples & C & DQ & DDRP & C & DQ & DDRP & C & DQ & DDRP \\
\hline \multicolumn{10}{|l|}{ Biogenic amines } \\
\hline Putrescine $-1 \mathrm{~d}$ & NF & $\mathrm{NF}$ & NF & $\mathrm{NF}$ & $\mathrm{NF}$ & $\mathrm{NF}$ & $\mathrm{NF}$ & NF & $\mathrm{NF}$ \\
\hline Putrescine $-365 \mathrm{~d}$ & traces & traces & traces & traces & traces & traces & traces & traces & traces \\
\hline Cadaverine $-1 \mathrm{~d}$ & NF & $\mathrm{NF}$ & NF & $\mathrm{NF}$ & $\mathrm{NF}$ & $\mathrm{NF}$ & $\mathrm{NF}$ & NF & $\mathrm{NF}$ \\
\hline Cadaverine $-365 d$ & traces & traces & traces & traces & traces & traces & traces & traces & traces \\
\hline Histamine - $1 \mathrm{~d}$ & NF & $\mathrm{NF}$ & $\mathrm{NF}$ & $\mathrm{NF}$ & $\mathrm{NF}$ & $\mathrm{NF}$ & $\mathrm{NF}$ & $\mathrm{NF}$ & NF \\
\hline Histamine $-365 d$ & traces & traces & traces & traces & traces & traces & traces & traces & traces \\
\hline Tyramine -1 d & NF & $\mathrm{NF}$ & $\mathrm{NF}$ & $\mathrm{NF}$ & $\mathrm{NF}$ & $\mathrm{NF}$ & $\mathrm{NF}$ & $\mathrm{NF}$ & $\mathrm{NF}$ \\
\hline Tyramine $-365 \mathrm{~d}$ & traces & traces & traces & traces & traces & traces & traces & traces & traces \\
\hline
\end{tabular}

C - control group lambs fed with ground alfalfa + pelleted compound feed

DQ - experimental groups lambs fed with the same diet supplemented with addition of $7.5 \mathrm{mg} \mathrm{DQ} / \mathrm{kg}$ life weight/d

DDRP - experimental groups lambs fed with the same diet supplemented with addition of $545 \mathrm{mg}$ dry distilled rose petals (DDRP)/kg life weight/d

$\mathrm{NF}$ - not found;

Traces - below the limit of detection (LoD) $10 \mathrm{mg} / \mathrm{kg}$; 
Table 6. Microbiological status of $\mathrm{m}$. Longissimus dorsi after one year ( $365 \mathrm{~d})$ of frozen storage at $-18^{\circ} \mathrm{C}$ obtained from animals fed with phytonutrient supplements

\section{Lamb tissue}

m. Longissimus dorsi

m. Semimembranosus

Perirenal adipose tissue

\section{Parameter}

C

DQ

DDRP

C

DQ

DDRP

C

DQ

DDRP

Aerobic plate count (APC),

$\lg \mathrm{cfu} / \mathrm{g}-1 \mathrm{~d}$

$4.25 \pm 0.02$

$4.20 \pm 0.03$

$4.27 \pm 0.01^{*}$

$4.24 \pm 0.01$

$4.21 \pm 0.02^{*}$

$4.22 \pm 0.01^{*}$

$4.29 \pm 0.02$

$4.24 \pm 0.01^{*}$

$4.29 \pm 0.02 *$

Aerobic plate count (APC),

$\lg \mathrm{cfu} / \mathrm{g}-365 \mathrm{~d}$

Total yeasts and molds count

(TYMC), $\lg \mathrm{cfu} / \mathrm{g}-1 \mathrm{~d}$

Total yeasts and molds

count (TYMC), lg cfu/g - 365 d

$5.26 \pm 0.02$

$4.85 \pm 0.01^{*} \quad 4.58 \pm 0.01^{*}$

$5.25 \pm 0.02^{*}$

$4.89 \pm 0.01^{*}$

$4.68 \pm 0.01^{*}$

$5.35 \pm 0.02 *$

$4.94 \pm 0.03$

$4.66 \pm 0.01^{*}$

$4.31 \pm 0.01^{*}$

$4.30 \pm 0.01^{*}$

$4.25 \pm 0.03^{*}$

$4.33 \pm 0.03^{*}$

$4.29 \pm 0.01^{*} \quad 4.28 \pm 0.01^{*}$

$4.34 \pm 0.02^{*}$

$4.31 \pm 0.01^{*}$

$4.32 \pm 0.02^{*}$

Psychrotrophic bacterial count (PBC), $\operatorname{lg~cfu} / \mathrm{g}-1 \mathrm{~d}$

$\mathrm{NF}^{* *}$

$\mathrm{NF}^{* *}$

$\mathrm{NF}^{* *}$

$\mathrm{NF}^{* *}$

$\mathrm{NF}^{* *}$

$\mathrm{NF}^{* *}$

$\mathrm{NF}^{* *}$

$\mathrm{NF}^{* *}$

$\mathrm{NF}^{* *}$

Psychrotrophic bacterial count

(PBC), lg cfu/g - $365 \mathrm{~d}$

\begin{tabular}{|c|c|c|c|c|c|c|c|c|}
\hline $3.73 \pm 0.01^{*}$ & $3.92 \pm 0.03^{*}$ & $3.91 \pm 0.01^{*}$ & $3.88 \pm 0.02^{*}$ & $3.73 \pm 0.02^{*}$ & $3.71 \pm 0.01^{*}$ & $4.00 \pm 0.01^{*}$ & $4.12 \pm 0.01^{*}$ & $4.11 \pm 0.01 *$ \\
\hline 5 & $4.60 \pm 0.01^{*}$ & $4.59 \pm 0.01^{*}$ & $4.26 \pm 0.01^{*}$ & $4.58 \pm 0.03^{*}$ & $4.57 \pm 0.01^{*}$ & $4.44 \pm 0.01^{\text {** }}$ & $4.48 \pm 0.02^{* *}$ & $4.47 \pm 0.02^{*}$ \\
\hline
\end{tabular}

C - control group lambs fed with ground alfalfa + pelleted compound feed

DQ - experimental groups lambs fed with the same diet supplemented with addition of $7.5 \mathrm{mg}$ DQ/kg life weight/d

DDRP - experimental groups lambs fed with the same diet supplemented with addition of $545 \mathrm{mg}$ dry distilled rose petals (DDRP)/kg life weight/d

Results are presented as Means \pm Standard error of the means (SEM); $n=10$

*- indicates significance $(\mathrm{p} \leq 0.05)$ of both factors (type of diet and time of frozen storage) and their interaction;

$* *$ - indicates significance $(\mathrm{p} \leq 0.05)$ for the factor time of storage only;

NF - not found; 